\title{
THE CORRECT NAME FOR DIDYMODON VALIDUS (BRYOPHYTA, POTTIACEAE) AT VARIETY RANK
}

\author{
RYSZARD OCHYRA ${ }^{1}$ \& HALINA BEDNAREK-OCHYRA
}

\begin{abstract}
Didymodon validus Limpr. is not universally recognised as a species in its own right but it is often considered a variety, D. rigidulus Hedw. var. validus (Limpr.) Düll. The epithet validus was used at varietal rank only in 1923, as Barbula rigidula (Hedw.) Mitt. var. valida (Limpr.) Broth., but this taxon was actually recognised as a variety, B. rigidula var. gigantea Schlieph. ex Warnst., already in 1904, and this name is lectotypified herein. Accordingly, the transfer of this variety to Didymodon Hedw., as D. rigidulus var. giganteus (Schlieph. ex Warnst.) Ochyra \& Bednarek-Ochyra, comb. nov., is effected. This is the correct name for this Central European-Central Asian montane taxon at variety rank. Didymodon validus is considered a new synonym of $D$. rigidulus var. giganteus.
\end{abstract}

Key words: Barbula, Didymodon rigidulus, Musci, nomenclature, priority, taxonomy, typification, varietal status

Ryszard Ochyra \& Halina Bednarek-Ochyra, Department of Bryology, W. Szafer Institute of Botany, Polish Academy of Sciences, ul.Lubicz 46,31-512Kraków,Poland; e-mail: rochyra@botany.pl \& h.bednarek@botany.pl

Didymodon validus was described as a new species by Limpricht (1888) but Möller (1907a, b) transferred it to the broadly conceived genus Barbula Hedw., which then served as an all-encompassing genus for most Barbula-like species of the Pottiaceae. Three specimens are cited in the protologue, two of which were collected in Austria and one in present-day Slovenia. This species name was lectotypified by J. Kučera in 1999 in his unpublished doctoral thesis (Jiménez 2006) but this lectotypification has apparently never been validly published, since the provisions of Art. 7.10 of the ICN (McNeill et al. 2012) have not been fulfilled. The lectotype of $D$. validus was designated only by Ochyra et al. (2011).

Didymodon validus is closely related to $D$. rigidulus Hedw.; the two species share similar leaf shape, curvature of the leaf margins, leaf areolation, the same shape of the axillary gemmae, and colour of the laminal cells in reaction with $\mathrm{KOH}$. The only real differences between these species are the smooth laminal and entirely unistratose leaf margins in D. validus. Therefore it has not

\footnotetext{
1 Corresponding author
}

gained universal acceptance as a species in its own right, and in many Floras and taxonomic treatments $D$. validus is considered a subspecies (Amann 1918; Loeske 1934; Podpěra 1954) or variety (Brotherus 1923; Düll 1984a, b, 1992; Düll \& Meinunger 1989; Kučera 1998, 2000, 2002; Grimms 1999; Cortini Pedrotti 2001) of $D$. rigidulus. Less often, $D$. validus is treated as a separate species (Nyholm 1956; Pilous \& Duda 1960; Schlüsslmayr 2005; Jiménez 2006; Meinunger \& Schröder 2007; Ochyra et al. 2011). It is also worth noting that this taxon has been entirely ignored in the latest checklist of European mosses (Hill et al. 2006).

Didymodon validus was reduced to subspecies rank by Amann (1918) in the catch-all genus Barbula as B. rigidula (Hedw.) Mitt. subsp. valida (Limpr.) J. J. Amann, and subsequently it was given the same taxonomic status in Didymodon Hedw. by Loeske (1934) as D. rigidulus Hedw. subsp. validus (Limpr.) Loeske. On the other hand, Brotherus (1923) reduced D. validus to variety within Barbula as B. rigidula var. valida (Limpr.) Broth. Düll (1984a) transferred this variety to Didymodon as D. rigidulus var. validus (Limpr.) 


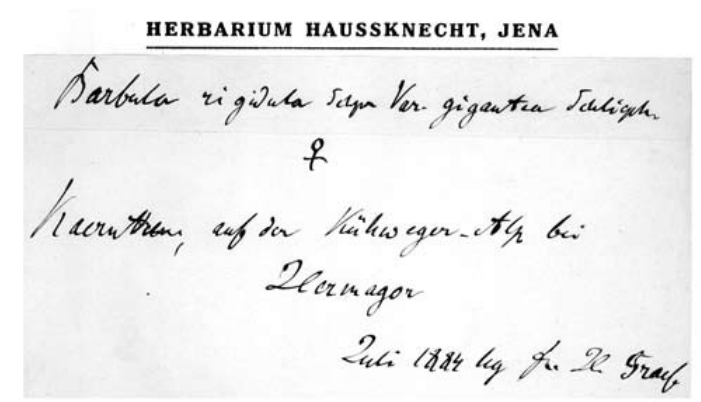

Fig. 1. The label of the lectotype of Barbula rigidula (Hedw.) Mitt. var. gigantea Warnst. (JE).

Düll. This name has unanimously been used by all aforementioned adherents of the varietal status of this taxon.

Didymodon rigidulus is not the oldest available name for this taxon at varietal rank. In 1885 K. Schliephacke annotated the specimen collected in 1884 by Graef in the Alps of Carinthia as Barbula rigidula var. gigantea Schlieph. In 1888 he sent this specimen to K. G. Limpricht, who determined it as Didymodon validus and included it as one of three syntypes in the protologue of this new species. Another duplicate was studied by C. Warnstorf who annotated it 'in litt. 1885' and subsequently briefly described and validated the epithet gigantea as Barbula rigidula var. gigantea Schlieph. ex Warnst. (Warnstorf 1904). He characterised it as a large, salient moss, to $4 \mathrm{~cm}$ tall, with the leaves to $2 \mathrm{~mm}$ long and $0.5 \mathrm{~mm}$ wide and incrassate walls of the laminal cells. In addition, he suggested its possible identity with Didymodon rigidulus var. major Podp., a variety described by Podpěra (1899) from the present-day Czech Republic. Later (Podpěra 1954) considered it to be a transitional form, Barbula rigidula subsp. rigidula fo. major (Podp.) Podp., between the type subspecies and Barbula rigidula subsp. valida.

Barbula rigidula var. gigantea has remained a neglected taxon; it was overlooked by the compilers of Index muscorum (Wijk et al. 1962, 1969). This name was formally considered a heterotypic synonym of Didymodon validus by Jiménez (2006), who erroneously ascribed it to K. Schliephacke. This decision concurs with the original concept of Limpricht (1888), who included the type of this variety in his concept of $D$. validus, but this name is lectotypified by another specimen originally used by this author for the description of this species. Nevertheless, Barbula rigidula var. gigantea is the oldest available name, published in 1904, for Didymodon validus at varietal rank, and it antedates Barbula rigidula var. valida which was given varietal rank only in 1923. The transfer of $B$. rigidula var. gigantea to Didymodon necessitates the following nomenclatural change.

Didymodon rigidulus Hedw. var. giganteus (Schlieph. ex Warnst.) Ochyra \& Bedn.-Ochyra, comb. nov.

BASIONYM: Barbula rigidula (Hedw.) Mitt. var. gigantea Schlieph. ex Warnst., Krypt.-Fl. Brandenburg 2 (Laubm.): 256. 1904 (18 Oct) [B. rigidula var. gigantea Schlieph. ex Limpr., Laubm. Deutschl. 1: 558. 1888 (May), nom. nud. in synon.]. TYPE CITATION: no specific specimen cited but an indirect reference by the authorship of $B$. rigidula var. gigantea 'Schlieph. [acke] in litt. 1885 ' to the specimen cited by Limpricht (1888) is given: 'Kärnthen: auf der Kühweger-Alp bei Hermagon leg. Graeff, comm. Schliephacke als Barbula rigidula var. gigantea Schlieph. in litt. 1888.' LeCtoTYPE (designated here): 'Barbula rigidula Schpr var. gigantea Schlieph. ㅇ Kaernthen, auf der Kühweger-Alp bei Hermagor Juli 1884 leg. Hr. H. Graeff' - JE! (Fig. 1); ISOTYPES: C, WB, not seen (vide Jiménez 2006: p. 270.

Didymodon validus Limpr., Laubm. Deutschl. 1: 557. 1888 (May) $\equiv$ Barbula valida (Limpr.) H. Möller, Bot. Not. 1907: 142. 1907 (15 May) $\equiv$ B. rigidula subsp. valida (Limpr.) J. J. Amann, Fl. Mouss. Suisse 2: 104. $1918 \equiv$ B. rigidula var. valida (Limpr.) Broth., Laubm. Fennosk.: 134. 1923 三Didymodon rigidulus Hedw. subsp. validus (Limpr.) Loeske, Sitzungsber. Naturhist. Vereins Preuss. Rheinl. 1932-1933(D): 17. $1934 \equiv$ D. rigidulus var. validus (Limpr.) Düll, J. Hattori Bot. Lab. 55: 263. $1984 \equiv$ Barbula acuta (Brid.) Brid. fo. valida (Limpr.) Nyholm, Ill. Fl. Nord. Mosses 2: 99. 1989, comb. inval. basion. not citat. TYPE CITATION: Wurde von P. Hieronymus Gander am 27. Juli 1882 an Kalkfelsen bei „Kalchstein“ nächst Innervillgraten in Tirol entdeckt. - Gebiet von Görz: An Strassenmauern bei Flitsch 400 m, Breidler am 17. August 1884. Kärnthen: auf der Kühweger-Alp bei Hermagon leg. Graeff, comm. Schliephacke als Barbula rigidula var. gigantea Schlieph. in litt. 1888. - LectotyPe (designated by Ochyra et al. 2011: p. 58): 'Barbula rigidula Hedw. [Austria] Tirol: Innervillgraten an Kalkfelsen 
bei „Kalchstein“ 27/7 1882 Breidler schreibt über dies Moss: 'üppige form, von B. viridiosa nur durch die lange stielrunde Blattspitze verschieden! Sehr interessante Uebergangsform. 'Didymodon validus n. sp.' - BP-Limpricht! SyntyPEs: (1) 'Aus dem Herbarium von A. Geheeb Didymodon validus Limpr. (plant female) Flora: von Görz. Fundort: an Strassenmauern bei Flitsch, 400 m, leg. J. Breidler, 17.8.84, com. Limpricht 1888'- JE-Herzog! (2) 'Barbula rigidula Schpr var. gigantea Schlieph. o Kaernthen, auf der Kühweger-Alp bei Hermagor Juli 1884 leg. Hr. H. Graeff' - JE!, syn. nov.

ACKNOwLEDGEMENTs. Thanks are due to the Curators at $\mathrm{BP}$ and JE for kindly allowing us to study the type specimens of Didymodon validus and Barbula rigidula var. gigantea, and to Rod D. Seppelt, Arundel, Australia, for checking the English and valuable suggestions, as well as to Vítězslav Plášek for his comment on the manuscript. This study has gained financial support through the statutory fund of the W. Szafer Institute of Botany of the Polish Academy of Sciences.

\section{REFERENCES}

Amann J. (with collaboration of Ch. Meylan \& P. Culmann). 1918. Flore des mousses de la Suisse. Deuxième partie. Bryogeographie de la Suisse. Imprimeries Réunies S.A., Lausanne.

Brotherus V. F. 1923. Die Laubmoose Fennoskandias. Societas pro Flora et Fauna Fennica, Helsingsfors.

Cortini Pedrotti C. 2001. Flora dei muschi d'Italia. Sphagnopsida, Andreaeopsida, Bryopsida (I parte). Antonio Delfino Editore, Medicina-Scienze, Roma.

DüLL R. 1984a. Taxonomy and distribution of some critical taxa of the genus Didymodon in Europe. J. Hattori Bot. Lab. 55: 259-266.

Düll R. 1984b. Distribution of the European and Macaronesian mosses (Bryophytina). Part I. Bryol. Beitr. 4: 1-113.

DüLl R. 1992. Distribution of the European and Macaronesian mosses (Bryophytina). Annotations and progress. Bryol. Beitr. 8/9: 1-223.

Düll R. \& Meinunger L. 1989. Deutschlands Moose. Die Verbreitung der deutschen Moose in der BR Deutschland und in der DDR, ihre Höchenverbreitung, ihre Arealentypen, sowie Angaben zum Rückgang der Arten. I. Teil: Anthocerotae, Marchantiatae Bryatae: Sphagnidae, Andreaeidae Bryidae: Tetraphidales - Pottiales. IDH-Verlag, Bad Münstereifel - Ohlerath.

Grimms F. (with collaboration of H. KöcKINGER, R. KRISAI, A. Schriebl, M. SuAnjaK, H. Zechmeister \& F. EhrenDORFER) 1999. Die Laubmoose Österreichs. Catalogue
Florae Austriae, II. Teil, Bryophyten (Moose), Heft 1, Musci (Laubmoose). Österreichische Akademie der Wissenschaften, Wien.

Hill M. O., Bell N., Bruggemann-Nannenga M. A., Bruguées M., Cano M. J., Enroth J., Flatberg K. I., Frahm J.-P., Gallego M. T., Garilleti R., Guerra J., Hedenäs L., Holyoak D. T., Hyvönen J., Ignatov M. S., Lara F., Mazimpaka V., Muñoz J. \& Söderström L. 2006. An annotated checklist of the mosses of Europe and Macaronesia. J. Bryol. 28: 198-167.

JiMÉNEZ J. A. 2006. Taxonomic revision of the genus Didymodon Hedw. (Pottiaceae, Bryophyta) in Europe, North Africa and Southwest and Central Asia. J. Hattori Bot. Lab. 100: 211-292.

KUČERA J. 1998. Determination key to the Czech species of the genus Didymodon Hedw. with notes on their ecology and distribution. Bryonora 22: 2-8 (in Czech with English abstract).

KUČERA J. 2000. Illustrierter Bestimmungsschlüssel zu den mitteleuropäischen Arten der Gattung Didymodon. Meylania 19: 2-48.

KUČERA J. 2002. Illustrerad bestästamningsnyckel till Didymodon i norra Europa. Myrinia 12: 2-40.

LimPricht K. G. 1888. Die Laubmoose Deutschlands, Oesterreichs und der Schweiz. I. Abtheilung: Sphagnaceae, Andreaeaceae, Archidiaceae, Bryineae (Cleistocarpae, Stegocarpae [Acrocarpae]). In: Dr. L. Rabenhorst's Kryptogamen-Flora von Deutschland, Oesterreich und der Schweiz. Ed. 2. 4(9): 513-576. Verlag von Eduard Kummer, Leipzig.

Loeske L. 1934. Ueber einige rheinische Didymodon-Formen. Sitzungsber. Naturhist. Vereins Preuss. Rheinl. 1932/1933(D): 16-19.

McNeill J., Barrie F. R., Buck W. R., Demoulin V., Greuter W., Hawksworth D. L., Herendeen P. S., Knapp S., Marhold K., Prado J., Prud'homme van Reine W. F., Smith G. F., Wiersema J. H. \& Turland N. J. (eds) 2012. International Code of Nomenclature for algae, fungi, and plants (Melbourne Code), adopted by the Eighteenth International Botanical Congress Melbourne, Australia, July 2011. Regnum Vegetabile 154. Koeltz Scientific Books, Königstein.

MeInunger L. \& SCHRÖDER W. 2007. Verbreitungsatlas der Moose Deutschlands. Band 2. Akrokarpe Laubmoose: Andreaeaceae bis Splachnaceae. Oliver Dürhammer für die Regensburgische Botanische Gesellschaft von 1790 e.V., Regensburg.

MÖLlER H. 1907a. Ett par upplysningar angående den snart utkomande förteckningen öfver Skandinaviens mossor. Bot. Not. 1907: 141-145.

MöLleR H. 1907b. Förteckning öfver Skandinaviens växter utgifven af Lunds Botaniska Förening. 2. Mossor. C.W.K. Glerup, Lund. 
NyноLм E. 1956. Illustrated moss Flora of Fennoscandia. II. Musci. Fasc. 2. CWK Gleerup, Lund.

Ochyra R., Stebel A. \& Bednarek-Ochyra H. 2011. Grimmia teretinervis (Grimmiaceae) and Didymodon validus (Pottiaceae), two moss species new to Poland. In: B. ZEMANEK (ed.), Geobotanist and taxonomist. A volume dedicated to Professor Adam Zajac on the $70^{\text {th }}$ anniversary of his birth, pp. 47-67. Institute of Botany, Jagiellonian University, Cracow.

Pilous Z. \& Duda J. 1960. Klič k určováni mechorostů ČSR. Nakladatelství Československé Akademie Věd, Praha.

Podpěra J. 1899. Bryologische Beiträge aus Südböhmen. Sitzungsber. Königl. Böhm. Ges. Wiss., Math.-Naturwiss. Cl. 1899: 1-28.

PoDPĚra J. 1954. Conspectus muscorum europaeorum. Nakladatelství Československé Akademie Věd, Praha.
SChLÜSSMAYR G. 2005. Soziologische Moosflora des südöstlichen Oberösterreich. Stapfia 84: i-xi + 1-695.

WARNSTORF C. 1904. Laubmoose. In: BotANISCHE VEREIN DER Provinz Brandenburg (ed.), Kryptogamenflora der Mark Brandenburg und angrenzender Gebiete. 2(2): 241-432. Verlag von Gebrüder Borntraeger, Leipzig.

WiJk R. van der, Margadant W. D. \& Florschütz P. A. 1962. Index muscorum. 2 (D-Hypno). Regnum Vegetabile 26. International Bureau for Plant Taxonomy and Nomenclature of the International Association of Plant Taxonomy, Utrecht.

Wijk R. van der, Margadant W. D. \& Florschütz P. A. 1969. Index muscorum. 5 (T-Z, Appendix). Regnum Vegetabile 65. International Bureau for Plant Taxonomy and Nomenclature of the International Association of Plant Taxonomy, Utrecht. 